казал, что высокий индивидуальный риск осложнений ХСН чётко ассоциируется с развитием систолической дисфункции, гипертрофией левого желудочка с дилатацией, анемическим и интоксикационным синдромами, ухудшением функции печени и почек с уменьшением уровня лептина крови, который имеет важные регулирующие функции. Таким образом, по проведённым логистическим, корреляционным и прогностическим анализам индивидуальный риск развития осложнений ХСН увеличивается при сочетании таких факторов, как уменьшение массы тела, снижение уровня общего холестерина и уменьшение количества лимфоцитов периферической крови. Использование разработанной компьютерной программы позволяет врачу рассчитать индивидуальный риск и наглядно его показать.

Ключевые слова: хроническая сердечная недостаточность; индивидуальный прогноз; масса тела; уровень общего холестерина; количество лимфоцитов; логистическая регрессия.

А. Б. КЕБКАЛО , В. В. ПОТОЧИЛОВАㄹ, І. М. МИЦЕНКО А. О. РЕЙТТ ${ }^{2}$, Б. Г. БОНДАРЧУК ${ }^{2}$, К. Л. РУДНЕВА ${ }^{2}$, О. В. ТКАЧУК

\title{
ПОРІВНЯЛЬНА ХАРАКТЕРИСТИКА ЛАБОРАТОРНИХ ДОСЛІДЖЕНЬ СЕПТИЧНИХ СТАНІВ ПРИ НЕКРОТИЧНОМУ ПАНКРЕАТИТІ
}

${ }^{1}$ Національна медична академія післядипломної освіти ім. П. Л. Шупика; ${ }^{2}$ Комунальний заклад Київської обласної ради «Київська обласна клінічна лікарня» $<$ vika.ptch@gmail.com>

\begin{abstract}
Мікробіологічна діагностика сепсису є головною у виборі адекватних режимів антибактеріальної терапії. Велику допомогу в діагностиці надає визначення концентрації прокальцитоніну, яка при сепсисі закономірно підвищується. При виборі адекватного лікування до ідентифікації збудника слід враховувати і можливість участі в інфекційному процесі мультирезистентних госпітальних штамів мікроорганізмів. Тест на прокальцитонін (ПКТ) - критерій, який використовують для контролю ефективності лікування сепсису, і одночасно - прогностичний маркер. Період напіврозпаду ПКТ 25-30 год. Тест на С-реактивний білок (СРБ) є одним з найбільи чутливих маркерів гострого запалення. Рівень СРБ може різко збільшитись в результаті перенесеного інфаркту міокарда, травми, інфекиій, запального процесу, хірургічного втручання. Збільшення відбувається впродовж 24-48 год, кількість СРБ може перевищувати норму у 2000 разів. При дослідженні пацієнтів з підозрою на бактеріальну інфекиію також може бути корисне послідовне серійне визначення рівня СРБ. Це дослідження призначають також при лікуванні антибактеріальними препаратами. При аналізі даних посіву крові на стерильність та результатів ПКТ має низький ступінь висіваності та високий ступінь визначення ПКТ при позитивному результаті.
\end{abstract}

Ключові слова: сепсис; прокальцитонін; С-реактивний білок; мікробіологічна діагностика; мультирезистентність.

Вступ. Бактеріальний сепсис (далі сепсис) є проблемою медичного, демографічного та економічного значення. У США щорічно реєструють близько 700000 випадків сепсису (3,5 на 10000 населення), у Франції його частота становить 6 на 1000 хворих у звичайних відділеннях і 119 - у відділеннях реанімації та інтенсивної терапії [8].

Незважаючи на багатий вибір антибактеріальних препаратів, летальність від сепсису за останні 50 років знизилася всього на $20 \%$ і становила на початку XXI ст. близько $40 \%$. Сепсис серед причин смерті знаходиться на 13-му місці. Щодня в Західній Європі від нього вмирають понад 1400 осіб [7]. 
Первинними септичними вогнищами, з яких мікроорганізми постійно або періодично надходять до кров'яного русла, можуть бути: будь-які гнійні рани, ділянки запалення в легенях, плевральній і черевній порожнинах, нирках тощо [10].

Розвиток септичного процесу ускладнюється поліорганною недостатністю. Важливими органами-мішенями є серце, легені та нирки. Порушення серцевої діяльності, обумовлене інтоксикацією, у поєднанні з дихальною недостатністю призводить до тяжкої гіпоксії. У переважної більшості хворих виявляють ознаки ураження легеневої паренхіми і системи сурфактанту, бактеріальний ендокардит, інфекційний або імунний гломерулонефрит, гострий інтерстиціальний нефрит, гнійний пієлонефрит [9].

Велику роль в діагностиці відіграє визначення концентрації прокальцитоніну (ПКТ), яка при сепсисі закономірно підвищується. Ступінь поліорганної дисфункції можна оцінити за бальними шкалами, в яких враховують респіраторні, коагуляційні, кардіоваскулярні, печінкові і ниркові показники (наприклад, шкала SOFA для оцінки недостатності пов'язаних із сепсисом органів) [12].

Мікробіологічна діагностика сепсису є головною у виборі адекватних режимів антибактеріальної терапії. При дотриманні суворих правил взяття біоматеріалу і використання сучасних методик позитивну гемокультуру визначають у 80-90\% випадків. Кров для посіву слід брати за 0,5-1 год до очікуваного ознобу під час лихоманки; забирають 3-5 порцій крові протягом дня кожна об'ємом 20-25 мл. Виділення мікроорганізму з крові (у нормі вона стерильна) зазвичай достатньо для встановлення етіологічного діагнозу [2]. Сучасні автоматизовані методи дослідження гемокультури дозволяють зафіксувати зростання колоній протягом 6-8 год інкубації (до 24 год), що забезпечує точну ідентифікацію збудника вже через 24-48 год.

До отримання даних бактеріального посіву і у разі необхідності початку проведення антибактеріальної терапії слід орієнтуватися на найбільш імовірні збудники залежно від локалізації первинного вогнища. Санацію первинного септичного вогнища здійснюють шляхом його широкого розтину з ретельною некректомією, додатковою обробкою рани пульсуючим струменем антисептиків, ультразвуком в низькочастотному діапазоні, вакуумом. Для місцевого лікування широко використовують антисептики, поверхнево-активні речовини, антибіотики широкого спектра дії, сульфаніламіди, мазі на гідрофільній основі, протеолітичні ферменти [5].

При виборі адекватного лікування до ідентифікації збудника слід враховувати і можливість участі в інфекційному процесі мультирезистентних госпітальних штамів мікроорганізмів.

У випадку гострого некротичного панкреатиту ПКТ - індикатор тяжкості перебігу та маркер інфекційних ускладнень. За даними деяких авторів, підвищення рівня ПКТ понад 1,8 нг/мл вказує на розвиток інфекційних ускладнень (чутливість - 80-95\%, специфічність - 88-93 \%). У хворих на тяжкий гострий панкреатит розвивається клініка синдрому системної запальної реакції (ССЗР). Дуже важливо прогнозувати у них вірогідність розвитку шоку і синдрому поліорганної недостатності (СПОН) і відповідно - необхідність раннього початку інтенсивної терапії. У пацієнтів з ССЗР ПКТ є найбільш точним прогностичним біомаркером можливості розвитку поліорганної недостатності.

ПРТ може бути маркером пневмонії, пов'язаної з швидкістю вентиляції легень (ШВЛ) (чутливість 78 \%, специфічність $97 \%$ ): рівень ПКТ > = 0,5 нг/мл свідчить про бактеріальну інфекцію та необхідність антибактеріальної терапії.

При рівні ПКТ $\geq 0,25$ нг/мл і < 0,5 нг/мл бактеріальна інфекція можлива. Питання про призначення антибіотиків слід вирішувати індивідуально.

У випадку інфекції нижніх відділів дихальних шляхів моніторування рівня ПКТ може оптимізувати тривалість антибактеріальної терапії: при рівні ПКТ $<0,25$ нг/мл лікування антибіотиками слід припинити.

Обгрунтування дослідження. Значні труднощі лікування хворих із септичною інфекцією багато в чому пов'язані із зростаючою поліантибіотикорезистентністю 
мікроорганізмів до більшості лікарських препаратів [1, 6]. До основних чинників, що спричинюють розвиток сепсису в хірургічних стаціонарах, належать:

1. Агресивна хіміотерапія та променева терапія хворих на онкологічні захворювання.

2. Збільшення застосування кортикостероїдних та імуносупресивних препаратів у пацієнтів з небактеріальними запальними захворюваннями і трансплантацією органів.

3. Динаміка демографічних показників: подовження тривалості періоду високого ризику виникнення сепсису - подовження тривалості життя і збільшення кількості осіб літнього віку, хворих на онкологічні захворювання та пацієнтів 3 тяжкими соматичними захворюваннями, діабетом, гранулоцитопенією.

4. Розвиток медицини, широке використання інвазивних пристроїв: хірургічних протезів, обладнання для дихальної та інгаляційної терапії, внутрішньосудинних і сечових катетерів, парентерального харчування.

5. Нераціональне застосування антимікробних препаратів, що створює умови для розмноження, колонізації та розвитку інфекції більш агресивними i peзистентними до антибіотиків мікроорганізмами.

Мета дослідження - визначити характер мікробного забруднення крові у хворих на некротичний панкреатит, оцінити рівень прокальцитоніну в крові при тяжких септичних станах паралельно з бактеріологічним посівом крові на стерильність та визначити рівень С-реактивного білка (СРБ) в крові. Порівняти рівень прокальцитоніну в крові, ріст мікроорганізмів при дослідженні крові на стерильність та показники рівня СРБ.

Матеріали і методи. У відділенні інтенсивної терапії в період з 2013 по 2015 р. обстежено 60 пацієнтів з гострим некротичним панкреатитом та септичним станом.

Матеріали для бактеріологічних досліджень на мікрофлору і чутливість до антибактеріальних препаратів відбирали під час підвищення температури тіла [12].

Кількісне та якісне визначення мікроорганізмів проводили шляхом посіву матеріалу на диференційно-діагностичні поживні середовища (агари): кров'яний, жовтково-сольовий, ентерокок агар, ендо агар, цукровий бульйон виробництва HiMedia (Індія) та ФДУ НДІЕМ ім. Пастера, С.-Петербург (РФ) (Федеральний Державний університет науково-дослідний інститут епідеміології та мікробіологіï) згідно з існуючими нормативними та методичними документами $[12,13]$. Ідентифікацію виділених бактерій проводили за Berdey's [3].

Ідентифікацію мікроорганізмів виконували на мікробіологічному аналізаторі VITEK 2 compact 15 (Франція). Ідентифікація грунтується на стандартних методах з використанням нових субстратів, що дозволяє оцінити утилізацію вуглеводів і ферментативну активність мікроорганізмів.

Необхідно враховувати, що рівень ПКТ підвищується тільки при генералізації бактеріальної інфекції (сепсис) і відображає iï ступінь, локальні вогнища не призводять до підвищення його рівня.

Принцип тесту на ПКТ об'єднує одноетапний «сандвіч» - метод імуноферментного аналізу з читанням флюоресценції кінцевого продукту. Усі кроки тесту контролюються аналізатором автоматично. Аналізатор фірми VIDAS (Франція).

Абсорбція реакційної суміші пропорційна концентрації СРБ в пробі. Референтне значення $<5$ мг/л. Кількісне визначення СРБ імунотурбідиметричним методом в сироватці та плазмі крові людини виконували на автоматичному біохімічному аналізаторі OLIMPUS AU 640 (дата останньої перевірки 17.11.2015 р.).

Результати та їх обговорення. Результати дослідження інтерпретували відповідно до наказу МОЗ України № 167 від 05.04.2007 р. «Про затвердження методичних вказівок “Визначення чутливості мікроорганізмів до антибактеріальних препаратів». 
За результатами досліджень у хірургічному відділенні отримали допомогу 60 пацієнтів із септичним станом. Серед обстежених виконано 60 досліджень крові на стерильність: у 48 - на ПКТ та у 55 - на СРБ.

Серед хворих у 17 з крові висівали культуру мікроорганізмів, а у 43 кров була стерильною, тобто результат був негативним (рисунок), дослідження на ПКТ мало дзеркально інше значення. При дослідженні крові пацієнтів хірургічного відділення з підозрою на сепсис тест на ПКТ проводили 48 обстеженим, з них у 18 були негативні результати, у 30 - позитивні, тобто значення > 0,15 нг/мл.

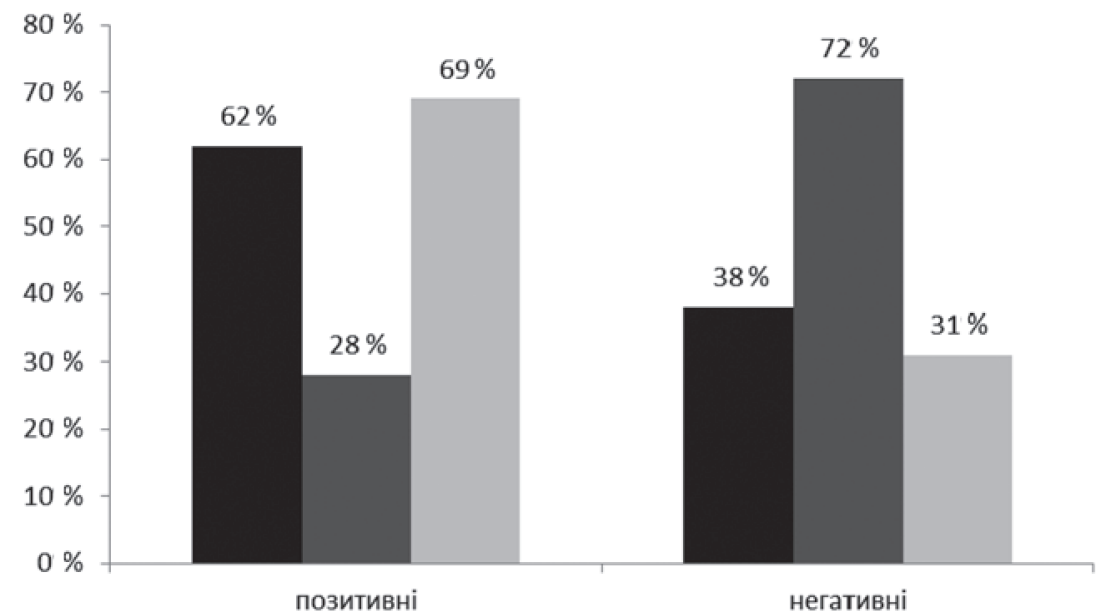

Розподіл результатів дослідження на стерильність крові $(\square)$, рівня С-реактивного білка та прокальцитоніну ( $\square$ )

Рівень СРБ у пацієнтів був таким: з позитивним результатом, тобто значення $>$ 5, було у 38 (69 \%) пацієнтів, негативний результат - у 17 (31 \%). Це можна пояснити тим, що пацієнти хірургічного відділення часто тривалий період отримують антибактеріальні препарати і тому важко отримати позитивний результат бактеріологічного дослідження хворих із сепсисом. У цьому випадку раціонально використовувати результати ПКТ. Метод точний та швидкий, результати отримують через 30 хв після забору матеріалу. Але якщо порівнювати ПСТ та СРБ, то і на СРБ слід звернути увагу, оскільки завдяки високій специфічності та швидкості виконання аналізу ми отримуємо результат на той самий день, а цінова різниця в 10 разів нижча, ніж при дослідженні ПКТ. С можливість оцінювати результати в динаміці.

Отже, у крові хворих на септис мікрофлора розподілялась таким чином: відсутність росту мікрофлори - у 72 \% (43 особи, позитивний результат - лише у $28 \%$ (43 пацієнти); таблиця.

Видовий спектр мікроорганізмів, виділений з крові хворих на сепсис

\begin{tabular}{lc}
\multicolumn{1}{c|}{ Флора } & Висівання, \% \\
\hline \hline Відсутність росту мікрофлори & 72 \\
Позитивний результат & 28 \\
Розподіл мікроорганізмів & \\
$\quad$ S. epidermidis & 54 \\
$\quad$ S. aureus & 6 \\
$\quad$ Enterococcus faecium & 4 \\
K. pneumonia & 12 \\
P. aeruginosa & 13 \\
A. baumannii & 7 \\
Інші мікроорганізми & 4 \\
\hline
\end{tabular}


Частіше виділяли S. epidermidis - у 54 \%, потім - P. aeruginosa та K. pneumonia у 13 та $12 \%$ відповідно.

Висновки. 1. При гострому некротичному панкреатиті має місце зниження ступеня висівання під час аналізу даних дослідження (посіву) крові на стерильність та результатів ПКТ і високе значення визначення ПКТ при позитивному результаті. 2. Під час дослідження крові на ПКТ та СРБ відсоток позитивного результату був у межах статистичної похибки, але цінова різниця при дослідженні ПКТ в 10 разів вища, ніж СРБ. 3. Можливість виконувати аналіз на СРБ в динаміці результативна і без значних фінансових затрат доводить ефективність визначення цього показника.

$$
\text { С пи сок л і т ер а т у и }
$$

1. Багрій О.С., Годлевський А. І., Бєлканія Г. С. Динаміка мікроциркуляторного відображення загоєння післяопераційних ран // Вісн. Він. держ. мед. ун-ту. - 2002. - № 2. C. 416-422.

2. Виноградов А.В.Дифференциальный диагноз внутренних болезней. - М.: Медицина, 1987. -806 c.

3. Визначник бактерій Берджі / Під ред. Дж. Хоулта. - М.: Мир, 1997. - 800 с.

4. Дж. Хоулта. Визначник бактерій Берджі / Під ред. Дж. Хоулта. - М.: Мир, 1997. $800 \mathrm{c.}$

5. Ерюхин И. А., Шляпников С. А. Хирургический сепсис //Мир медицины. - 1998. № $11-12 .-$ C. 46.

6. Желіба М. Д., Превар А. П., Фуніков А. П. Оптимізація комплексного лікування гострих гнійно-запальних захворювань м'яких тканин // Рани м'яких тканин та ранова інфекція. - К., 2005. - С. 28.

7. Зубков M. Н. Сбор, транспортировка биологического материала и трактовка результатов микробиологических исследований // Клин. микробиология и антимикробная химиотерапия. - 2004. - № 2. C. 143-154.

8. Приказ ЖОб унификации микробиологических методов исследования применяемых в клинико-диагностических лабораториях ЛПУ 》№ 535 от 22.04.85 г.

9. Руднов B. A. Сепсис: современный взгляд на проблему // Клин. антимикробная химиотерапия. - 2000. - Т. 2, № 1. - С. 4-10.

10. Яковлев C. В. Программы микробиологической диагностики и антибактериальной терапии сепсиса // Инфекции и антимикробная терапия. - 2001. - Т. 3, № 3 [Електронний ресурс]// Режим доступу: http:// old.consilium-medicum.com/media/ infektion/01 03/90.shtml.

11. Michie H. R., Wilmore D. W. Sepsis, signal and surgical sequel // Arch. Aurg. - 1990. - Vol. 125. P. 580-593.

12. James E. Frampton and Monique P. Curran // Tigecycline. Drugs. - 2005. - Vol. 65, N 18. P. 2623-2635.

13. Vincent J. L. The SOFA (Sepsis-related Organ Failure Assessment) score to describe organ Dysfunction/failure // Intensive Care Med. - 1996. - Vol. 22. - P. 707-710.
1. Bagrij O. S., Godlevs'kij A. I., Belkaniya G.S. Dinamika mikrocirkulyatornogo vidobrazhennya zagoennya pislyaoperacijnih ran // Visn. Vin. derzh. med. un-tu. - 2002. № 2. - S. 416-422. vnutrennih boleznej. - M.: Medicina, 1987.$806 \mathrm{~s}$.

3. Viznachnik bakterij Berdzhi / Pid red. Dzh. Houlta. - M.: Mir, 1997. - 800 s.

4. Dzh. Houlta. Viznachnik bakterij Berdzhi / Pid red. Dzh. Houlta. - M.: Mir, 1997. $800 \mathrm{~s}$.

5. Eryuhin I. A., SHlyapnikov S. A. Hirurgicheskij sepsis //Mir mediciny. - 1998. - № 1112. - S. 46-52.

6. Zheliba M. D., Prevar A. P., Funikov A. P. Optimizaciya kompleksnogo likuvannya gostrih gnijno-zapal'nih zahvoryuvan' m'yakih tkanin // Rani m'yakih tkanin ta ranova infekciya. - K., 2005. - S. 28.

7. Zubkov M. N. Sbor, transportirovka biologicheskogo materiala i traktovka rezul'tatov mikrobiologicheskih issledovanij // Klin. mikrobiologiya i antimikrobnaya himioterapiya. - 2004. - № 2. - S. 143-154.

8. Prikaz «Ob unifikacii mikrobiologicheskih metodov issledovaniya primenyaemyh v kliniko - diagnosticheskih laboratoriyah LPU» № 535 ot $22.04 .85 \mathrm{~g}$.

9. Rudnov $V$. A. Sepsis: sovremennyj vzglyad na problemu // Klin. antimikrobnaya himioterapiya. -2000 . - T. 2, № 1. - S. 4-9.

10. Yakovlev $S$. V. Programmy mikrobiologicheskoj diagnostiki i antibakterial'noj terapii sepsisa // Infekcii i antimikrobnaya terapiya. - 2001. - T. 3, № 3 [Elektronnij resurs]// Rezhim dostupu: http://old.consilium-medicum.com/media/infektion/ 01 03/90.shtml.
2. Vinogradov A. V. Differencial'nyj diagnoz

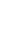




\title{
СРАВНИТЕЛЬНАЯ ХАРАКТЕРИСТИКА \\ ЛАБОРАТОРНЫХ ИССЛЕДОВАНИЙ СЕПТИЧЕСКИХ СОСТОЯНИЙ ПРИ НЕКРОТИЧЕСКОМ ПАНКРЕАТИТЕ
}

\author{
А. Б. Кебкало, В. В. Поточилова, И. Н. Мыценко, И. М. Яцик, \\ А. А. Чантуридзе, А. О. Рейти, Б. Г. Бондарчук, К. Л. Руднева, \\ О. В. Ткачук, В. А. Гордовский (Киев)
}

\begin{abstract}
Микробиологическая диагностика сепсиса является основной при выборе адекватных режимов антибактериальной терапии. Большую помощь в диагностике оказывает определение концентрации прокальцитонина, которая при сепсисе закономерно повышается. При выборе адекватного лечения до идентификации возбудителя следует учитывать и возможность участия в инфекционном процессе мультирезистентных госпитальных штаммов микроорганизмов. Тест на прокальцитонин (ПКТ) - критерий, который используют для контроля эффективности лечения сепсиса, и одновременно - прогностический маркер. Период полураспада ПКТ - 25-30 ч. Тест на С-реактивный белок (СРБ) является одним из наиболее чувствительных маркёров острого воспаления. Уровень СРБ может резко увеличиться в результате перенесённого инфаркта миокарда, травмы, инфекции, воспалительного процесса, хирургического вмешательства. Увеличение происходит в течение 24-48 ч, количество СРБ может превышать норму в 2000 раз. При обследовании пациентов с подозрением на бактериальную инфекцию также может быть полезно последовательное серийное определение уровня СРБ. Это исследование назначают также при лечении антибактериальными препаратами. При анализе данных посева крови на стерильность и результатов ПКТ имеет место низкая степень высеваемости и высокий уровень определения ПКТ при положительном результате.
\end{abstract}

Ключевые слова: сепсис; прокальцитонин; С-реактивный белок; микробиологическая диагностика; мультирезистентность.

\section{COMPARATIVE CHARACTERISTICS OF LABORATORY STUDIES OF SEPTIC CONDITIONS IN NECROTIC PANCREATITIS}

\author{
A. B. Kebkalo', V. V. Potochilova², I. M. Mytsenko², I. M. Yatsyk², \\ A. A. Chanturidze ${ }^{2}$, A. O. Reiti', B. G. Bondarchuk ${ }^{2}$, K. L. Rudneva ${ }^{2}$, \\ O. V. Tkachuk', V. A. Gordovskiy ${ }^{1}$ (Kiev, Ukraine) \\ ${ }^{1}$ National Medical Academy of Postgraduate Education. P. L. Shupika; \\ ${ }^{2}$ Kiivska Regional Clinical
}

Microbiological diagnosis of sepsis is fundamental in the selection of adequate regimens for antibiotic therapy. A great help in diagnostics is the determination of the concentration of procalcitonin, which is naturally elevated when sepsis. When choosing the appropriate treatment before identifying the pathogen, it is also necessary to consider the possibility of participation in the infectious process of multi-resistant hospital strains of microorganisms. Procalcitonin test (PCT) is a criterion used to control the effectiveness of sepsis treatment and at the same time a prognostic marker. The half-life of PKT is 25-30 hours. The C-reactive protein (CRP) test is one of the most sensitive markers of acute inflammation. The level of CRP may increase dramatically as a result of myocardial infarction, injury, infection, inflammation, and surgical intervention. The increase takes place within 24-48 hours, the amount of CRP can exceed the norm by 2000 times. In the examination of patients suspected of bacterial infection, serial serum determination of CRP level may also be useful. This study is also prescribed in the treatment of antibacterial drugs. When analyzing blood culture data for sterility and PKT results, we have a low seeding rate and a high level of PCT determination with a positive result.

Key words: sepsis; procalcitonin; C-reactive protein; microbiological diagnostics; multiresistance. 